Research Paper

\title{
Inhibitory activity of Syzygium aromaticum and Cymbopogon citratus (DC.) Stapf. essential oils against Listeria monocytogenes inoculated in bovine ground meat
}

\author{
Thales Leandro Coutinho de Oliveira ${ }^{1}$, Maria das Graças Cardoso ${ }^{2}$, \\ Rodrigo de Araújo Soares ${ }^{1}$, Eduardo Mendes Ramos ${ }^{1}$, Roberta Hilsdorf Piccoli ${ }^{1}$, \\ Victor Maximiliano Reis Tebaldi ${ }^{3}$ \\ ${ }^{1}$ Universidade Federal de Lavras, Departamento de Ciência dos Alimentos, \\ Laboratório de Microbiologia dos Alimentos, Lavras, MG, Brazil. \\ ${ }^{2}$ Universidade Federal de Lavras, Departamento de Química, Laboratório de Química Orgânica, Lavras, \\ MG, Brazil. \\ ${ }^{3}$ Centro Universitário de Barra Mansa, Rio de Janeiro, RJ, Brazil.
}

Submitted: November 30, 2011; Approved: September 10, 2012.

\begin{abstract}
This research evaluated the antimicrobial effect of the clove (Syzygium aromaticum) and lemongrass (Cymbopogon citratus (DC.) Stapf.) essential oils (EOs) against Listeria monocytogenes ATCC 19117 growth added to bovine ground meat stored under refrigeration $\left(5 \pm 2{ }^{\circ} \mathrm{C}\right)$ for three days. The EOs, extracted by hydrodistillation and analyzed by gas chromatography-mass spectrometry (GCMS), were tested in vitro using an agar well diffusion methodology for determination of Minimum Inhibitory Concentration (MIC). The MIC concentrations for both essential oils on culture tested of L. monocytogenes were $1.56 \%$. The EOs concentrations applied in contaminated ground beef were $1.56,3.125$ and $6.25 \%(\mathrm{w} / \mathrm{v})$ based on MIC levels and possible activity reductions by food constituents. The bacteria populations were significantly reduced $(\mathrm{p} \leq 0.05)$ after one day of storage in ground meat samples treated with clove and lemongrass EOs at concentrations of $1.56 \%$. There were no significant counts of $L$. monocytogenes in samples at the other concentrations of the two oils applied after the second day of storage. The sensory acceptability evaluation of the bovine ground meat samples treated with EOs showed that the addition at concentrations higher than $1.56 \%$ promote undesirable alterations of taste, odor and characteristic color. The application of EOs at low concentrations in food products can be used in combination with other preservation methods, such as refrigeration, to control pathogens and spoilage bacteria during shelf-life; which goes according to current market trends, where consumers are requesting natural products.
\end{abstract}

Key words: clove, lemongrass, food safety, Listeria monocytogenes, sensorial.

\section{Introduction}

Meats are highly perishable foods, easily contaminated, with wide nutritional composition, sufficient water activity and favorable $\mathrm{pH}$ for growth of most microorganisms. Ground meat is defined as a meat product obtained from the ground muscle mass of cattle carcasses, followed by instant refrigeration or freezing (Brasil, 2003). Ground beef is a food that has a large surface area and is highly manipulated, facts which favors bacterial growth; fresh ground meats are frequently preserved by refrigeration, and the pathogenic and spoilage psychrotrophic bacteria, especially L. monocytogenes, are the main causes of their deterioration process and foodborne illness (Mantilla et al., 2007).

Listeria species have been isolated from various sources such as soil, decomposing plant material, silage, animal feed, asymptomatic carriers and can consequently contaminate a wide variety of raw and processed products

Send correspondence to: T.L.C. Oliveira. Universidade Federal de Lavras, Department of Food Science, Laboratory of Food Microbiology; $37200-000$ Lavras, MG, Brazil. E-mail: thalesteco@hotmail.com. 
such as meats, raw milk, cheese among others. Listeria monocytogenes is a psychrotrophic, Gram-positive bacterium that can adapt, survive and grow in a wide range of environmental conditions and a variety of foods, including meat and meat products. Illnesses caused due to the consumption of contaminated foods with pathogenic microorganisms such as L. monocytogenes have a wide economic and public health impact worldwide (Gandhi and Chikindas, 2007). Due to their psychrotrophic character, $L$. monocytogenes control becomes difficult in chilled foods. The occurrence of these bacteria in food products can promote an eating disorder called listeriosis. This is a serious infection caused by eating food contaminated with this pathogen and has been recognized as an important public health problem, affecting primarily pregnant women, newborns and adults with weakened immune systems (Dimitrijevic et al., 2007; Gandhi and Chikindas, 2007).

For the elimination of pathogenic microorganisms in food, common technologies for preservation and shelf life extension of foods are used and among these stand out the use of chemical preservatives. These techniques can control the development of undesirable microorganisms in foods; however their use is not compatible with the call for "natural products" of market reality, besides the possible toxic and carcinogenic effect of these agents to the human organism; so alternative preservation techniques such as the use of natural antimicrobials are being studied for use in food products (Gutierrez et al., 2009). In this context, plant essential oils (EOs) are gaining interest for their potential as preservative ingredients or decontaminating treatments, as they have a GRAS (Generally Recognized as Safe) status and wide consumer acceptance (Burt, 2004). EOs are the odorous, volatile products of aromatic plant secondary metabolisms, with biological properties, normally formed in special cells or groups of cells found in many leaves and stems (Oussalah et al., 2007). Despite the antimicrobial properties of EOs being widely recognized, the current interest in an antimicrobial derived from natural products has led to intensification of work employing these compounds. Several in vitro studies have reported the high efficiency of biocidal EOs on pathogens that cause food poisoning and spoilage bacteria (Dorman and Deans, 2000; Elgayyar et al., 2001; Canillac and Mourey, 2004; Gill and Holley, 2004; Oussalah et al., 2007; Gutierrez et al., 2008; Muños et al., 2009; Pereira et al., 2009). However, higher concentrations than those found in $\mathrm{EO}$ in vitro assays are necessary for finding the same antimicrobial effect on food models (Burt, 2004). If EOs are expected to be widely applied as antibacterial, the organoleptical impact should be considered since the use of naturally derived preservatives can alter the taste of food or exceed acceptable flavor thresholds (Hsieh, 2001; Nazer et al., 2005).

This research was aimed to evaluate the antimicrobial effect of clove (Syzygium aromaticum) and lemongrass
(Cymbopogon citratus (DC.) Stapf.) EOs on Listeria monocytogenes growth in bovine ground meat stored under refrigeration $\left(5 \pm 2{ }^{\circ} \mathrm{C}\right)$ for three days. In addition, this study also aimed evaluated the sensorial acceptability of the ground beef treated with the tested EOs at different concentrations.

\section{Materials and Methods}

\section{Plant material and EOs extraction}

Fresh leaves of lemongrass (C. citratus) were collected at the Medicinal Plant Nursery of the Federal University of Lavras located in Lavras, Minas Gerais, Brazil (2114'43" S; 4459'59" W; altitude $919 \mathrm{~m}$ ). The harvest was carried out in January 2009, in the morning, with mild temperatures and absence of rain period. Dry clove flower buds (S. aromaticum) were acquired in a retail location. For confirmation, both vegetal species were submitted a characterization procedure at botany sector of Federal University of Lavras. The EO was extracted by hydrodistillation using a modified Clevenger apparatus. Plant material was placed with water in a $6000 \mathrm{~mL}$ volumetric distillation flask. The flask was coupled to the modified Clevenger apparatus, and the extraction was performed for $3 \mathrm{~h}$ with the temperature maintained at $100 \pm 5^{\circ} \mathrm{C}$. The obtained hydrolate (water/oil fraction) was centrifuged at $321.8 \mathrm{~g}$ for 10 min at $25^{\circ} \mathrm{C}$. The EO was collected with a Pasteur pipette, and the water traces were removed with anhydrous sodium sulfate (Vetec ${ }^{\circledR}$, Brazil). The oil was stored under refrigeration temperature $\left(5 \pm 2{ }^{\circ} \mathrm{C}\right)$ in glass flasks wrapped in aluminum foil (Guimarães et al., 2008).

\section{Chemical characterization of EOs}

The EO chemical components were identified by gas chromatography coupled to mass spectrometry (GC-MS). A Shimadzu gas chromatograph (model GC 17A) equipped with a mass selective detector (model QP 5000) was operated under the following conditions: fused silica capillary column (30 m x $0.25 \mathrm{~mm}$ ) coated with a DB-5 MS stationary phase; ion source temperature of $220^{\circ} \mathrm{C}$; column temperature programmed at an initial temperature of $40^{\circ} \mathrm{C}$, and increased by $3{ }^{\circ} \mathrm{C} / \mathrm{min}$ up to $240{ }^{\circ} \mathrm{C}$; helium carrier gas ( $1 \mathrm{~mL} / \mathrm{min})$; initial column pressure of $100.2 \mathrm{kPa}$; split ratio of $1: 10$ and volume injected of $1 \mu \mathrm{L}$ ( $1 \%$ solution in dichloromethane). The following conditions were used for the mass spectrometer (MS): impact energy of $70 \mathrm{eV}$; decomposition velocity of 1000 , decomposition interval of 0.50 and fragments of 45 Daltons and 450 Daltons decomposed. A mixture of linear hydrocarbons $\left(\mathrm{C}_{9} \mathrm{H}_{20} ; \mathrm{C}_{10} \mathrm{H}_{22}\right.$; $\left.\mathrm{C}_{11} \mathrm{H}_{24} ; \mathrm{C}_{24} \mathrm{H}_{50} ; \mathrm{C}_{25} \mathrm{H}_{52} ; \mathrm{C}_{26} \mathrm{H}_{54}\right)$ was injected under identical conditions. The mass spectra obtained were compared to those of the database (Wiley 229), and the Kovats retention index $(\mathrm{KI})$ calculated for each peak was compared to the values according to Adams (Adams, 2007). 
Quantification of the EO constituents was carried out using a Shimadzu gas chromatograph (model GC 17A) equipped with a flame ionization detector (FID) under the following conditions: DB5 capillary column; column temperature programmed from an initial temperature of $40^{\circ} \mathrm{C}$ finalizing at a temperature of $240{ }^{\circ} \mathrm{C}$; injector temperature of $220^{\circ} \mathrm{C}$; detector temperature of $240{ }^{\circ} \mathrm{C}$; nitrogen carrier gas $(2.2 \mathrm{~mL} / \mathrm{min})$; split ratio of $1: 10$; volume injected of $1 \mu \mathrm{L}(1 \%$ solution in dichloromethane) and column pressure of $115 \mathrm{kPa}$. Quantification of each constituent was obtained by means of area normalization (\%).

\section{Bacterial strain, standardization, inoculum preparation and storage}

The microorganism used was Listeria monocytogenes ATCC 19117 acquired from Oswaldo Cruz Foundation - (Rio de Janeiro-Brazil). The bacterial strain was reactivated in Trypic Soy Broth medium (TSB, Merk ${ }^{\circledR}$ ) at $37^{\circ} \mathrm{C}$ for $24 \mathrm{~h}$; after the strain grew, the bacterial cells were pelleted by centrifugation ( $5000 \mathrm{~g}$ for $5 \mathrm{~min}$ at $24^{\circ} \mathrm{C}$ ), covered by freezing culture medium $\left(15 \%\right.$ glycerol Vetec ${ }^{\circledR}$, Brazil; $0.5 \%$ bacteriological peptone and $0.3 \%$ of yeast extract, Biolife Italiana $\mathrm{Srl}$, Italy; and $0.5 \%$ of $\mathrm{NaCl}$, final $\mathrm{pH}$ of $7.2 \pm 0,2)$ and maintained under a freezing temperature $\left(-20{ }^{\circ} \mathrm{C}\right)$ throughout the experiment. For bacterial reactivation and use, an aliquot of the freezing culture medium was transferred to test tubes containing TSB and grown with two subcultures. The standardization of cell counts was carried out by the growth curve. Bacterial populations in the inoculum were determined with a spectrophotometer (CARY Varian Inc.) by optical density (periodic absorbance readings) at $600 \mathrm{~nm}$ in culture media TSB broth. Throughout the growth curve, cell counts were determined as $\log \mathrm{CFU} / \mathrm{ml}$ by serial dilution in peptone water $0.1 \%$ $(w / v)$ and subsequent enumeration on Tryptic Soy Agar (TSA, Merk ${ }^{\circledR}$ ) by a spread plate methodology.

\section{Determination of Minimum Inhibitory Concentration (MIC)}

To evaluate the inhibitory activity of essential oil, the Agar Well Diffusion method, with slight modifications was used (Deans and Ritchie, 1987). Ten sterilized glass spheres (volume of $10 \mathrm{~mm}^{3}$ ) were distributed on a previously solidified layer of TSA agar that was poured in $150 \mathrm{~mm}$ plates followed by another layer of the same molten culture medium at $45 \pm 2{ }^{\circ} \mathrm{C}$, inoculated with revealing culture of L. monocytogenes at concentrations of $10^{8}$ $\mathrm{cfu} / \mathrm{mL}$. After solidification the glass spheres were removed to microwells formation, where $10 \mu \mathrm{L}$ of EOs diluted in dimethylsulfoxide DMSO $\left(\left(\mathrm{CH}_{3}\right)_{2} \mathrm{SO}\right.$; Vetec ${ }^{\circledR}$, Brazil) were dispensed, at concentrations of 50.0; 25.0; $12.5 ; 6.25 ; 3.125 ; 1.56 ; 0.78 ; 0.39 \%$ and $0.0 \%$ with the latter being the negative control. A positive control was prepared with a $1000 \mathrm{mg} / \mathrm{L}$ chloramphenicol solution. The plates were incubated at $37^{\circ} \mathrm{C}$ for $24 \mathrm{~h}$, and inhibition zones were measured (mm) with a digital caliper (Digimess ${ }^{\circledR}$, Brazil). The MIC was defined as the lowest EOs concentration applied able to inhibit the visible growth of the tested microorganism (Delaquis et al., 2002).

\section{Ground meat and samples preparation}

Refrigerated, vacuum packaged beef (Longissimus dorsi) was obtained within $48 \mathrm{~h}$ of slaughtering from a local meat packer. After sanitizing the outer surface with $70 \%$ ethanol, the package was opened and pieces of meat rendered in a BECCARO ${ }^{\circledR}$ model PB22 grinder, grinding disc number four; all equipment was previously sanitized. After processing, the samples of ground beef were aseptically weighed and stored in sterile flasks, then were inoculated with $10^{6} \mathrm{cfu} / \mathrm{g}$ of L. monocytogenes viable cells and treated with EOs at effective concentrations (1.56, 3.125 and $6.25 \% \mathrm{w} / \mathrm{v}$ ) obtained in tests of minimum inhibitory concentration (MIC) in vitro. The samples were stored under controlled refrigeration temperature $\left(5 \pm 2{ }^{\circ} \mathrm{C}\right)$, and analyzed after 1, 2 and 3 days of storage. The controls were prepared without addition of EO in ground beef inoculated with the target microorganism and in samples without oil and microorganism inoculum.

\section{Listeria monocytogenes cells enumeration}

For the enumeration of L. monocytogenes, $10 \mathrm{~g}$ of the ground meat samples were weighed, transferred into sterile stomaching bags, combined with $90 \mathrm{~mL}$ of sterile peptone water $(0.1 \% \mathrm{w} / \mathrm{v})$ and homogenized in a Stomacher (Metroterm, Brazil) with 490 strokes/min for $2 \mathrm{~min}$ at room temperature. Stomached slurries were decimal serially diluted in peptone water $(0.1 \% \mathrm{w} / \mathrm{v})$, and aliquots $(100 \mu \mathrm{L})$ of the sample dilutions were spread on selective differential Agar Oxford (MOX Merck ${ }^{\circledR}$ ) and incubated at $37^{\circ} \mathrm{C}$ for $24 \mathrm{~h}$; the characteristic colonies were counted using a colony counter.

Microbiological control was performed to verify the hygienic-sanitary conditions of ground beef samples and the possible presence of accompanying microbiota that could affect the development of the target microorganism. For this propose the Plate Count Agar (PCA medium) was used to estimate the Total Plate Count $\left(37^{\circ} \mathrm{C} / 24 \mathrm{~h}\right)$ and psychrotrophic count.

\section{Sensory evaluation}

\section{Acceptance evaluation}

The sensory acceptance evaluation of ground beef samples treated with clove and lemongrass EOs at different concentrations was performed at Sensory analysis laboratory of the Food Science Department at Federal University of Lavras. A twenty member non-trained panel was used to evaluate sensory attributes of color, smell and overall acceptability. Panelists were selected among university stu- 
dents, staff and professors of the department, belonging for both sexes and aged between 20 and 50 years. Treated ground meat samples were weighed, individually packaged in aluminum foil and roasted at $180 \pm 10{ }^{\circ} \mathrm{C}$ for $20 \mathrm{~min}$; subsequently each sample was served warm randomly to the judges in dishes, with standard quantities and coded with three digits obtained from a table of random numbers. A 9-point hedonic scale was used to score sensory attributes, where 9-like extremely, 8-like very much, 7-like moderately, 6-like slightly, 5-neither like nor dislike (limit of acceptability), 4-dislike slightly, 3-dislike moderately, 2-dislike very much,1-dislike extremely. Sensory evaluation was accomplished at 1,2 and 3 of refrigerated storage at $5 \pm 2{ }^{\circ} \mathrm{C}$

\section{Objective color evaluation}

Color measurements were taken with a colorimeter (Chroma Meters CR-300, Konica Minolta Sensing Inc.) established at a $10^{\circ}$ angle for the observer and illuminated at $\mathrm{D}_{65}$ to calculate color indices in the CIELAB system, following the recommendations of Ramos and Gomide (2007). The color parameters lightness $\left(L^{*}\right)$, redness $\left(a^{*}\right)$ and yellowness $\left(b^{*}\right)$ were obtained from an average of nine readings taken at different points in ground beef patties samples approximately $40 \mathrm{~mm}$ wide.

\section{Data statistical analysis}

The data were obtained from three independent experiments and the means were from triplicate results. The data obtained were subjected to analysis of variance (ANOVA), and the comparison between means was determined by Scott-Knott test adopting a 5\% significance level. The statistical analyses of data were carried out using statistical R software (2004).

\section{Results and Discussion}

\section{EOs characterization}

The chemical composition of studied EOs obtained by GC-MS analysis, and their concentrations quantified by normalization areas through examining the chromatogram obtained obtained by GC-FID detector are shown in Table 1. EOs can be comprised of more than sixty individual components, and the major components can constitute up to $85 \%$ of the oil fraction, whereas the other components are present only as a trace (Burt, 2004). According to the results three chemical components for $S$. aromaticum EO and eight for $C$. citratus were identified. The major chemical constituent found in clove EO was eugenol $(89.80 \%)$ and in lemongrass they were neral (30.90\%) and geranial (42.90\%); according to Lewinsohn et al. (1998) the lemongrass produces $75-85 \%$ of citral in its EO. Citral is the name given to a natural mixture of two isomeric acyclic monoterpene aldehydes: Geranial ((2E)-3,7-dimetilocta-2,6-dienal, citral A or E isomer)
Table 1 - Chemical constituents of Syzygium aromaticum and Cymbopogon citratus essential oil identified by GC-MS and their contents.

\begin{tabular}{lcc}
\hline Compound & IK* calculated & Content $(\%)$ \\
\hline S. aromaticum & 1354 & 89.80 \\
eugenol & 1417 & 5.88 \\
trans-caryophyllene & 1453 & 2.30 \\
$\alpha$-humulene & - & 2.02 \\
Others & & 100.00 \\
Total & & \\
\hline C. citratus (DC.) Stapf. & 991 & 1.3687 \\
Myrcene & 1040 & 0.1402 \\
(Z)- $\beta$-ocimene & 1051 & 0.2024 \\
(E)- $\beta$-ocimene & 1199 & 1.5175 \\
Linalool & 1244 & 30.9096 \\
Neral & 1254 & 1.1770 \\
Geraniol & 1273 & 42.9192 \\
Geranial & 1292 & 4.1296 \\
2-undecanone & - & 17.6358 \\
others & & 100.00 \\
Total & & \\
\hline
\end{tabular}

IK Kovats index.

and Neral ((2Z)- 3,7-dimetilocta-2,6-dienal, citral B or Z isomer). The phytochemical profiles found in this analysis are similar to those observed by several authors for $S$. aromaticum (Tomaíno et al., 2005; Oussalah et al., 2006; Pereira et al., 2008) and for C. citratus (Fandohan et al., 2008; Blanco et al., 2009; Oliveira et al., 2010). The final composition of EO is genetically influenced, being specific to each organ and its stage of development, the climatic conditions of plant collection site, degree of terrain hydration and level of macro and micronutrients, in addition to drying conditions to which the plant material was exposed (Bakkali et al., 2008).

\section{Antimicrobial activity and minimum inhibitory concentration}

The inhibition zones formation proved the antimicrobial effect of $C$. citraus and S. aromaticum EO. The values observed for the diameter of inhibition zones in determining the minimum inhibitory concentration (MIC) of EO on L. monocytogenes are shown in Figure 1. The variable "concentration" evaluated, was significant for clove $\left(\mathrm{p}=3.231 \mathrm{e}^{-05}\right)$ and for lemongrass $\left(\mathrm{p}=1.003 \mathrm{e}^{-05}\right)$. The formation of inhibition zones with an average diameter of $4.33 \mathrm{~mm}( \pm 0.33)$ for $S$. aromaticum and $5.33 \mathrm{~mm}( \pm 0.33)$ for $C$. citraus was observed at concentrations of $1.56 \%$ which was determined as the Minimum Inhibitory Concentration (MIC). The minimum inhibitory concentration is cited by most researchers as the measure of performance of antibacterial essential oils (Burt, 2004). In negative control 

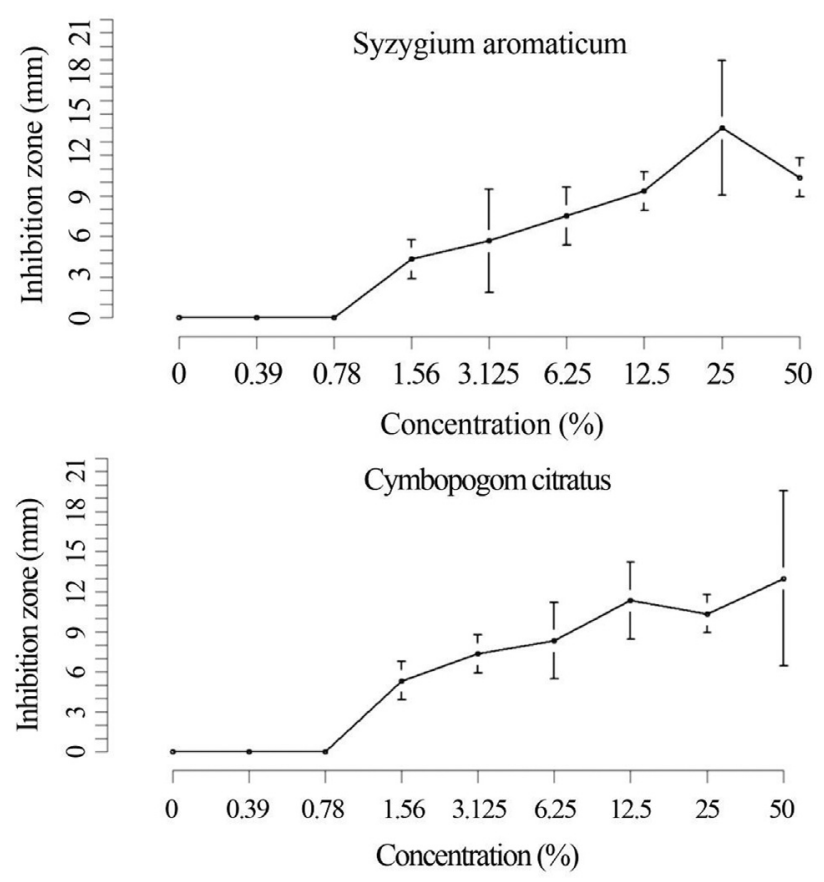

Figure 1 - Inhibition zones diameters ( $\mathrm{mm}$ ) by different concentrations of (A) Syzygium aromaticum and (B) Cymbopogon citratus essential oils on Listeria monocytogenes ATCC 19117. Mean values \pm Standard error (bars), without considering the well diameter.

(wells filled with DMSO without EO) inhibition zones were not observed, a fact that demonstrates the non-interference of the diluent used in antimicrobial performance tests. The EO and some of their major constituents were tested in vitro and in food models by several authors, and have demonstrated proven antimicrobial activity against $L$. monocytogenes (Vrinda-Menon and Garg, 2001; Singh et al., 2003; Gill and Holley, 2004; Lin et al., 2004; Mytle et al., 2006; Oussalah et al., 2007). Considering the large number of different groups of chemical compounds present in EOs, it is most likely that their antibacterial activity is not attributable to one specific mechanism but that there are several targets in the cell. An important characteristic of EOs is their hydrofobicity, a fact which allows the partition of the lipids in the bacterial cell membrane disturbing its structure and function (Sikkema et al., 1994; Sikkema et al., 1995). The $\mathrm{K}^{+}$efflux is usually the first signal of damage and often is followed by leakage of cytoplasmatic constituents including ATP. The loss of differential permeability of the cytoplasmatic membrane is considered the cause of cell death. Other events that could lead to dysfunction of the membrane and subsequent disruption include dissipation of the two components of the proton motive force $(\mathrm{pH}$ gradient and electrical potential), both by changes in ion transport or depolarization, through changes in membrane structure; interference with the energy generating system of (ATP) in the cell; enzymatic inhibition and preventing sub- strate utilization for energy production (Helander et al., 1998; Cox et al., 2000; Lambert et al., 2001; Ultee et al., 2002). The antimicrobial activity of clove EO is attributed to the presence of eugenol its major constituent (Beuchat, 2000; Pereira et al., 2008). Filgueiras and Vanetti (2006) related that eugenol acts on the lipid constituents of the bacterial cell membrane resulting in the loss of intracellular constituents which is evidenced by the release of $\mathrm{K}^{+}$. Smith-Palmer et al. (1998) observed that clove EO at concentrations of 400 and $500 \mu \mathrm{g} / \mathrm{mL}$, inhibited the $L$. monocytogenes growth inoculated in TSB broth at 4 and $35^{\circ} \mathrm{C}$. The antimicrobial effect of $C$. citratus was demonstrated on several yeasts strains (Sacchetti et al., 2005), mycotoxigenic fungi (Tzortzakis and Economakis, 2007), L. monocytogenes biofilms (Oliveira et al., 2010), pathogenic and spoilage bacteria (Helander et al., 1998). The $C$. citratus $\mathrm{EO}$ obtained in the research presents monoterpenes as major compounds; according to Sikkema et al. (1995) the monoterpenes action on bacterial cell involves mainly toxic effects on the structure and function of the cell membrane. As a result of their lipophilic character, the monoterpenes will preferably dislocate from the aqueous phase towards the membrane structures.

\section{Antimicrobial activity in bovine ground meat}

The variations of $L$. monocytogenes population in ground meat bovine treated with EOs during storage under refrigeration are shown in Table 2. In control samples, without added of EOs, populations of 4.91 and $6.39 \log _{10}$ $\mathrm{cfu} / \mathrm{g}$ were observed for assays with $C$. citratus and $S$. aromaticum respectively on the first day of storage. These counts remained significantly unchanged during the storage time $(p>0.05)$ in control samples (without oil) evidencing the psychrotolerance mechanisms of the evaluated microorganism. Listeria monocytogenes has a minimum growth temperature of around $2{ }^{\circ} \mathrm{C}$. Low temperatures exert profound effects on the bacteria growth, through influence on ribosomes, cytoplasmic membranes, changes in protein synthesis and solute uptake. In recent studies, more emphasis has been given to increasing the expression of bacterial proteins promoted by cold shock (CSPs) in response to reduced temperatures (Wouters et al., 2000). A few studies have examined the molecular mechanisms of psychrotolerance in L. monocytogenes. Frequently refrigeration is the only method of preservation used for ground beef processing, and its abuse during processing or any of the links in the supply chain (cold storage, transportation, retailing, transportation and home consumer storage) can accelerate the development of $L$. monocytogenes. (Mytle et al., 2006). Consequently, the refrigeration should not be used as the only method to control this organism; the use of other combined preservation methods such as EO, can be a feasible alternative. In ground beef samples treated with EOs at concentrations of $1.56 \%(\mathrm{w} / \mathrm{v})$, reduced populations $(\mathrm{p} \leq 0.05)$ were ob- 
Table 2 - Populations of Listeria monocytogenes ATCC $19117\left(\log _{10} \mathrm{cfu} / \mathrm{g}\right)$ in bovine ground meat treated with clove and lemongrass essential oils during storage under refrigeration temperature $\left(5 \pm 2{ }^{\circ} \mathrm{C}\right)$ for three days.

\begin{tabular}{lcccc}
\hline Essential Oil & Concentration (\%) & \multicolumn{3}{c}{$\log _{10}$ cfu/g days of storage } \\
\cline { 3 - 5 } & & 1 & 2 & 3 \\
\hline S. aromaticum & 0.00 & $6.39( \pm 0.04) \mathrm{aA}$ & $6.37( \pm 0.05) \mathrm{aA}$ & $6.30( \pm 0.15) \mathrm{aA}$ \\
S. aromaticum & 6.250 & $0.33( \pm 0.33) \mathrm{aE}$ & $0.00( \pm 0.00) \mathrm{aE}$ & $0.00( \pm 0.00) \mathrm{aD}$ \\
S. aromaticum & 3.125 & $3.42( \pm 0.06) \mathrm{aD}$ & $0.00( \pm 0.00) \mathrm{bE}$ & $0.00( \pm 0.00) \mathrm{bD}$ \\
S. aromaticum & 1.560 & $4.24( \pm 0.13) \mathrm{aC}$ & $3.66( \pm 0.05) \mathrm{aC}$ & $1.72( \pm 0.37) \mathrm{bC}$ \\
C. citratus & 0.00 & $4.91( \pm 0.05) \mathrm{aB}$ & $4.80( \pm 0.03) \mathrm{aB}$ & $4.92( \pm 0.06) \mathrm{aB}$ \\
C. citratus & 6.250 & $0.00( \pm 0.00) \mathrm{aE}$ & $0.00( \pm 0.00) \mathrm{aE}$ & $0.00( \pm 0.00) \mathrm{aD}$ \\
C. citratus & 3.125 & $0.00( \pm 0.00) \mathrm{aE}$ & $0.00( \pm 0.00) \mathrm{aE}$ & $0.00( \pm 0.00) \mathrm{aD}$ \\
C. citratus & 1.560 & $3.10( \pm 0.13) \mathrm{aD}$ & $1.33( \pm 0.88) \mathrm{bD}$ & $0.00( \pm 0.00) \mathrm{cD}$ \\
\hline
\end{tabular}

Means values \pm Standard error.

Values followed by the different small letter within the same line, and by the different capital letter within the same column, are significantly different $(\mathrm{p} \leq 0.05)$ according to Scott-Knott test.

Initial inoculum of L. monocytogenes $10^{6} \mathrm{cfu} / \mathrm{g}$.

served in relation to the control for $C$. citratus and $S$. aromaticum on the first day of storage; the viable cell counts of L. monocytogenes decreased ( $\mathrm{p} \leq 0.05)$ during the storage time in these treatments. The most pronounced reductions were observed in samples with added EOs at higher concentrations for both plant specimens evaluated. At concentrations of 3.125 and $6.25 \%(\mathrm{w} / \mathrm{v})$ significant counts after the second day of storage, were not detected. Vrinda-Menon and Garg (2001), studying the effect of clove $\mathrm{EO}$ on L. monocytogenes in minced meat, found that the addition of $0.5 \%$ of the oil restricted the initial bacterial population growth from $7.7 \times 10^{3}$ to $1.8 \times 10^{5} \mathrm{cfu} / \mathrm{g}$ after a day of storage at $30{ }^{\circ} \mathrm{C}$; while the corresponding control increased from $8,7 \times 10^{3}$ to $2,6 \times 10^{6} \mathrm{cfu} / \mathrm{g}$. The application of higher amounts of clove EO (1\%) improved the action on microorganism in these studies.

The application of EOs for the control of pathogens and spoilage bacteria requires the evaluation of their effectiveness in food products or models that simulate roughly the composition of foods. Generally the efficiency of some additives and natural antimicrobial agents can be reduced by certain components of foods; if higher concentrations of EO are generally required when added to food to maintain product safety, undesirable flavor and sensory changes can occur (Gutierrez et al., 2008; Gutierrez et al., 2009). In general, it is assumed that high levels of fat or protein food may protect the bacteria from the action of essential oils; the essential oil dissolved in the lipid phase of the food is relatively less available for action on bacteria present in the aqueous phase. The considered levels of fat and protein found in meat can prejudice the antimicrobial activity. Gutierrez et al. (2009) evaluated the effect of food components in activity of thyme and oregano essential oils on $L$. monocytogenes and observed that fat at concentrations higher than 5\% decrease the antimicrobial effect. Gill et al. (2002) suggests that the viability of major nutrients in foods compared to the laboratory mediums may enable the bacteria to repair damaged cells faster. In this respect not only the intrinsic properties of food (fat, protein, water content, antioxidants, preservatives, $\mathrm{pH}$, salt and other additives are important but extrinsic factors are decisive (temperature, modified atmosphere packaging and characteristics of the microorganism) and can affect the bacterial sensitivity (Burt, 2004).

\section{Sensory evaluation}

Sensory evaluation scores of ground meat bovine treated with EOs at different concentrations during refrigerated storage are shown in Figure 2. Table 3 shows the color objective parameters $L^{*}, a^{*}, \mathrm{~b}^{*}$ during storage according to different treatments evaluated. The addition of EOs at concentrations of $1.56 \%$ impaired the sensory acceptance, showing significantly reduced scores $(p \leq 0.05)$ for taste and overall acceptability attributes. However, for smell attribute, the addition of EOs at concentrations of $1.56 \%$ revealed higher scores $(p>0.05)$ than control samples. In treatments added of both EOs at 3.125 and $6.25 \%$, scores were detected below the rejection point (limit of acceptability) for all attributes evaluated. The color parameters lightness, redness and yellowness were significantly affected when compared to control by the addition of EOs at concentration higher than $1.56 \%$; this fact suggest the possible characteristic color alteration, and rejection from costumers. The adverse sensorial effect of higher amounts EO addition, such as observed in this study, were described by Hayouni et al. (2008) and Solomakos et al. (2008) in minced meat and Govaris et al. (2010) in minced sheep meat. 

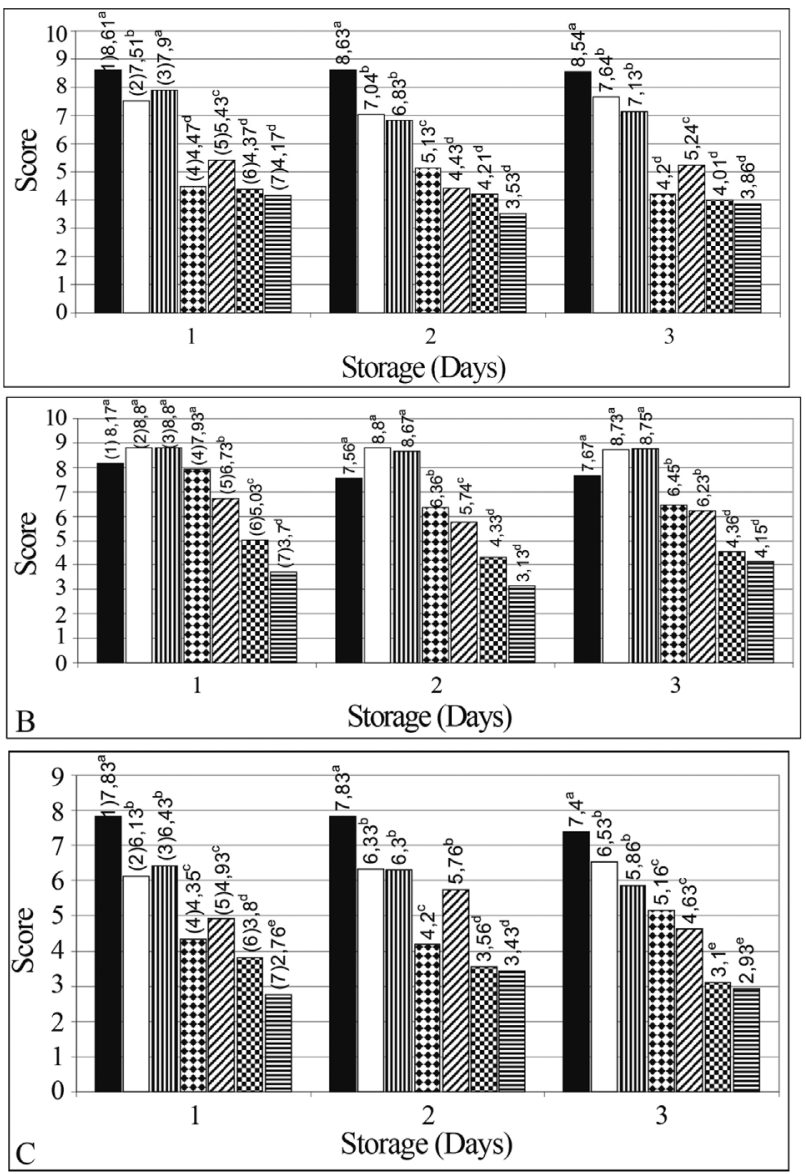

Figure 2 - Sensory acceptance profile of bovine ground meat added with essential oils during refrigerated storage at $4 \pm 2{ }^{\circ} \mathrm{C}$ for three days. Attributes: Taste (A), Odour (B), (C) Overall Acceptability. Mean values. Values followed by the different letter are significantly different $(\mathrm{p} \leq 0.05)$ according to Scott-Knott test. Treatments: (1) Control; (2) $1.56 \%$ clove EO; (3) $1.56 \%$ lemongrass EO; (4) $3.125 \%$ clove EO; (5) $3.125 \%$ lemongrass EO; (6) $6.25 \%$ clove EO; (7) $6.25 \%$ lemongrass EO. Variation coefficients: (A) $9.27 \%$; (B) $10.88 \%$; (C) $7.78 \%$.

\section{Conclusion}

The antimicrobial activity of clove (S. aromaticum) and lemongrass (C. citratus) EOs was confirmed in tests in vitro and bovine ground meat. However, the sensorial evaluation showed the negative effect on organoleptic attributes with EOs applied at MIC concentration. The most promising application is the use of EO in conjunction with other preservation techniques to develop a synergistic alternative to current methods. The application of EOs to control pathogenic and spoilage microorganisms in food requires an evaluation of several aspects: sensory, concentration required for activity, chemical composition of food and interference to the antimicrobial action, in addition the characteristics of the microorganism studied.

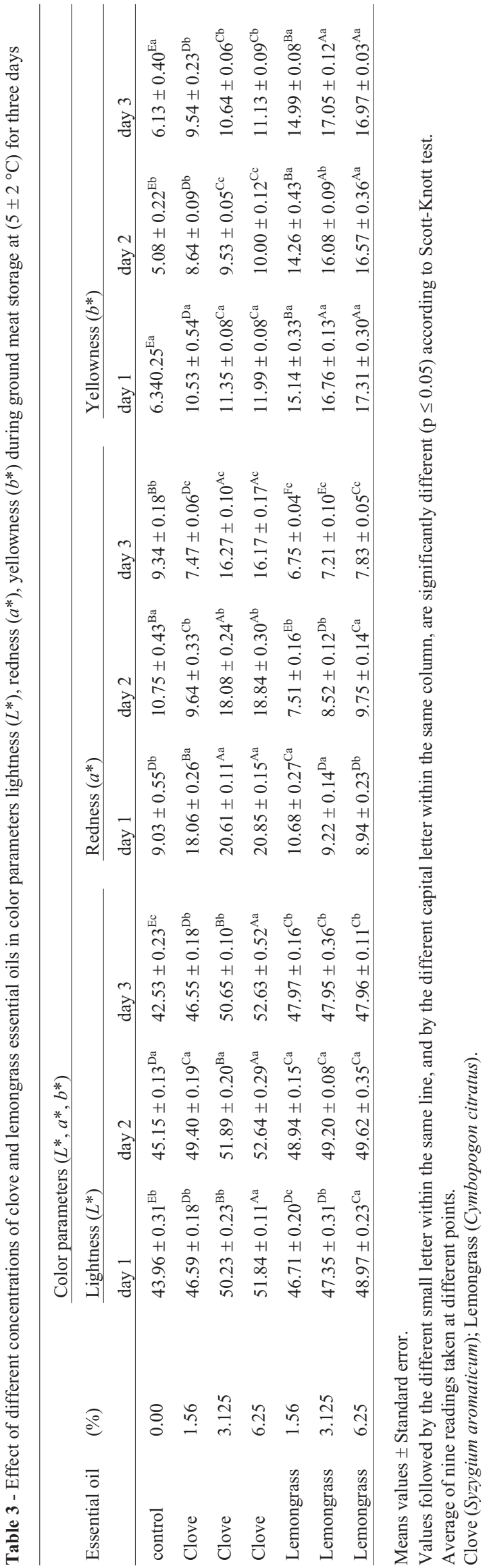




\section{Acknowledgments}

This research was funded by the National Council for Scientific and Technological Development, CNPq, and CAPES, Brazil.

\section{References}

Adams RP (2007) Identification of essential oils componets by gás chromatography/quadrupole mass spectroscopy. Carol Stream: Allured Publishing, 4 ed.804 p.

Bakkali F, Averbeck S, Averbeck D, Idaomar M (2008) Biological effects of essential oils - a review. Food Chem Toxicol 46:446-475.

Beuchat LR (2000) Control of foodborne pathogens and spoilage microorganisms by naturally occurring antimicrobials. In: Wilson, C.L. \& Droby, S. (eds). Microbial Food Contamination. Boca Raton, FL: CRC Press, p.149-169.

Blanco MM, Costa CARA, Freire AO, Santos JrJG, Costa M (2009) Neurobehavioral effect of essential oil of Cymbopogon citratus in mice. Phytomedicine 16:265-270.

BRASIL. Ministério da Agricultura Pecuária e Abastecimento. Regulamento técnico de identidade e qualidade de carne moída de bovino. Decreto n ${ }^{\circ} 4.629$, de 21 de março de 2003.

Burt S (2004) Essential oils: their antibacterial properties and potential applications in foods - a review. Int J Food Microbiol 94:223- 253.

Canillac N, Mourey A (2004) Effects of several environmental factors on the anti-Listeria monocytogenes activity of an essential oil of Picea excelsa. Int J Food Microbiol 92:95- 103.

Cox SD, Mann CM, Markham JL, Bell HC, Gustafson JE, Warmington TR, Wyllie SG (2000) The mode of antimicrobial action of the essential oil of Melaleuca alternafolia (tea tree oil). J Appl Microbiol 88:170-175.

Deans SG, Ritchie G (1987) Antibacterial properties of plant essential oils. Int J Food Microbiol 5:165-180.

Delaquis PJ, Stanich K, Girard B, Mazza G (2002) Antimicrobial activity of individual and mixed fractions of dill cilantro coriander and eucalyptus essential oils. Int J Food Microbiol 74:101-109.

Dimitrijevic SI, Mihajlovski KR, Antonovic DG, Milanovic- Stevanovic MR, Mijin DZ (2007) A study of the synergistic antilisterial effects of a sub-lethal dose of lactic acid and essential oils from Thymus vulgaris L., Rosmarinus officinalis L. and Origanum vulgare L. Food Chem 104:774-782.

Dorman HJD, Deans SG (2000). Antimicrobial agents from plants: antibacterial activity of plant volatile oils. J. Appl Microbiol 88:308-316.

Elgayyar M, Draughon FA, Golden DA, Mount JR (2001) Antimicrobial activity of essential oils from plants against selected pathogenic and saprophytic microorganisms J Food Protect 64:1019-1024.

Fandohan P, Gnonlonfin B, Laleye A, Gbenou JD, Darboux R, Moudachirou M (2008) Toxicity and gastric tolerance of essential oils from Cymbopogon citratus, Ocimum gratissimum and Ocimum basilicum in Wistar rats. Food Chem Toxicol 46:2493-2497.

Filgueiras CT, Vanetti MCD (2006) Effect of Eugenol on growth and listeriolysin O Production by Listeria monocytogenes. Braz Arch Biol Tech 49:405-409.
Gandhi M, Chikindas ML (2007) Listeria: a foodborne pathogen that knows how to survive. Int J Food Microbiol 113:1-15.

Gill AO, Holley RA (2004) Mechanisms of Bactericidal Action of Cinnamaldehyde against Listeria monocytogenes and of Eugenol against L. monocytogenes and Lactobacillus sakei. Appl Environ Microbiol 70:5750-5755.

Gill AO, Delaquis P, Russo P, Holley RA (2002) Evaluation of antilisterial action of cilantro oil on vacuum packed ham. Int J Food Microbiol 73:83-92.

Guimarães LGL, Cardoso MG, Zacaroni LM, Lima RK, Pimentel FA, Morais AR (2008) Influence of light and temperature on the oxidation of the essential oil of lemongrass (Cymbopogon citratus (D.C.) Stapf). Quim Nova 31:1476-1480.

Gutierrez J, Barry-Ryan C, Bourke P (2009) Antimicrobial activity of plant essential oils using food model media: Efficacy, synergistic potential and interactions with food components. Food Microbiol 26:142-150.

Gutierrez J, Barry-Ryan C, Bourke P (2008) The antimicrobial efficacy of plant essential oil combinations and interactions with food ingredients. Int J Food Microbiol 124:91-97.

Helander IM, Alakomi H-L, Latva-Kala K, Mattila-Sandholm T, Pol I, Smid EJ, Gorris LGM Wright A (1998) Characterization of the action of selected essential oil components on Gram-negative bacteria. J Agric Food Chem 46:3590-3595.

Hsieh PC, Mau JL, Huang SH (2001) Antimicrobial effect of various combinations of plant extracts. Food Microbiol 18:3543.

Lambert RJW, Skandamis PN, Coote P, Nychas G-JE (2001) A study of the minimum inhibitory concentration and mode of action of oregano essential oil, thymol and carvacrol. J Appl Microbiol 91:453-462.

Lewinsohn L, Dudai N, Tadmor N, Katzir I, Ravid U, Putievsky E, Joel DM (1998) Histochemical localization of Citral acumulation in Lemongrass leaves (Cymbopogon citrates (DC.) Stapf., Poaceae). Ann Bot 81:35-39.

Lin YT, Labbe RG, Shetty K (2004) Inhibition of Listeria monocytogenes in fish and meat systems by use of oregano and cranberry phytochemical synergies. Appl Environ Microbiol 70:5672-5678.

Mantilla SPS, Franco RM, Oliveira LAT, Santos EB, Gouvêa R (2007) Occurrence of Listeria spp. in bovine ground meat samples commercialized in Niterói, RJ, Brazil. Cienc Agrotecnol 31:1225-1230.

Muñoz M, Guevara L, Palop A, Tabera J, Fernandez PS (2009) Determination of the effect of plant essential oils obtained by supercritical fluid extraction on the growth and viability of Listeria monocytogenes in broth and food systems using flow cytometry. $L W T$ - Food Sci Technol 42:220-227.

Mytle N, Anderson GL, Doyle MP, Smith MA (2006) Antimicrobial activity of clove (Syzgium aromaticum) oil in inhibiting Listeria monocytogenes on chicken frankfurters. Food Control 17:102-107.

Nazer AI, Kobilinsky A, Tholozana JL, Dubois-Brissonneta F (2005) Combinations of food antimicrobials at low levels to inhibit the growth of Salmonella sv. Typhimurium: a synergistic effect? Food Microbiol 22:391-398.

Oliveira MMM, Brugnera DF, Cardoso MG, Alves E, Piccoli RH (2010) Disinfectant action of Cymbopogon sp. essential oils in different phases of biofilm formation by Listeria monocytogenes on stainless steel surface. Food Control 21:549-553. 
Oussalah M, Caillet S, Saucier L, Lacroix M (2007) Inhibitory effects of selected plant essential oils on the growth of four pathogenic bacteria: E. coli O157:H7, Salmonella Typhimurium, Staphylococcus aureus and Listeria monocytogenes. Food Control 18:414-420.

Oussalah O, Caillet S, Saucier L, Lacroix M (2006) Antimicrobial effects of selected essential oils on the growth of Pseudomonas putida strains isolated from meat. Meat Sci 73:236-244.

Pereira AA, Cardoso MG, Abreu LR, Morais AR, Guimarães LG, Salgado APSP (2008) Caracterização química e efeito inibitório de óleos essenciais sobre o crescimento de Staphylococcus aureus e Escherichia coli. Cienc. Agrotecnol 32:887-893.

R DEVELOPMENT CORE TEAM (2004) A language and environment for statistical computing. Viena: R Foundation for Statistical Computing. Avaliable at http://www. R - project. org. Accessed January 10, 2010.

Sacchetti G, Maietti S, Muzzoli M, Scaglianti M, Manfredini S, Radice M, Bruni R (2005) Comparative evaluation of 11 essential oils of different origin as functional antioxidants, antiradicals and antimicrobials in foods. Food Chem 91:621-632.

Sikkema J, De Bont JAM, Poolman B (1994) Interactions of cyclic hydrocarbons with biological membranes. J Biol Chem 269:8022-8028.

Sikkema J, De Bont JAM, Poolman B (1995) Mechanisms of membrane toxicity of hydrocarbons. Microbiol Rev 59:201-222.

Singh A, Singh RK, Bhunia AK, Singh N (2003) Efficacy of plant essential oils as antimicrobial agents against Listeria monocytogenes in hotdogs. Lebensm. Wiss. Technol 36:787-794.

Smith-Palmer A, Stewart J, Fyfe L (1998) Antimicrobial properties of plant essential oils and essences against five important food-borne pathogens. Lett Appl Microbiol 26:118-122.

Tomaino A, Cimino F, Zimbalatti V, Venuti V, Sulfaro V, De Pasquale A, Saija A (2005) Influence of heating on antioxi- dant activity and the chemical composition of some spice essential oils. Food Chem 89:549-554.

Tzortzakis NG, Economakis CD (2007) Antifungal activity of lemongrass (Cympopogon citratus L.) essential oil against key postharvest pathogens. In Food Sci Emer Technol 8:253-258.

Ultee A, Bennink MHJ, Moezelaar R (2002) The phenolic hydroxyl group of carvacrol is essential for action against the food-borne pathogen Bacillus cereus. Appl Environ Microbiol Washington 68:1561-1568.

Vrinda Menon K, Garg SR (2001) Inhibitory effect of clove oil on Listeria monocytogenes in meat and cheese. Food Microbiol 18:647-650.

Wouters JA, Rombouts FM, Kuipers OP, De Vos WM, Abee T (2000) The role of cold-shock proteins in low-temperature adaptation of food related bacteria. Syst Appl Microbiol 23:165-173.

Ramos EM \& Gomide LAM (2007) Assessment of quality of meats: principles and methodologies. Viçosa: Ed. UFV.

Govaris A, Solomakos N, Pexara A, Chatzopoulou PS (2010) The antimicrobial effect of oregano essential oil, nisin and their combination against Salmonella Enteritidis in minced sheep meat during refrigerated storage. Int J Food Microbiol 137:175-180.

Hayouni A, Chraief I, Abedrabba M, Bouix M, Leveau J, Mohammed H, Hamdi M (2008) Tunisian Salvia officinalis L. and Schinus molle L. essential oils: Their chemical compositions and their preservative effects against Salmonella inoculated in minced beef meat. Int J Food Microbiol 125:242-251.

Solomakos N, Govaris A, Koidis P, Botsoglou N (2008)The antimicrobial effect of thyme essential oil, nisin and their combination against Escherichia coli O157:H7 in minced beef during refrigerated storage. Meat Sci 80:159-166.

All the content of the journal, except where otherwise noted, is licensed under a Creative Commons License CC BY-NC. 